\title{
Branding of a (Desti)nation with a Deteriorated Image: The Case of Serbia
}

\author{
Branka Novčić Korać \\ University of Belgrade, Faculty of Organizational Sciences, Serbia \\ e-mail: novcic.branka@fon.bg.ac.rs
}

\section{Tina Š egota ${ }^{1}$}

University of Ljubljana, Faculty of Economics, Slovenia

e-mail: tina.segota@ef.uni-lj.si

\begin{abstract}
This paper offers insights into the differentiation between nation branding and destination branding and how important it is for the successful rebranding of a country with a deteriorated and negative image. It is on the case of Serbia that authors wish to demonstrate how a country engages in competitive marketing strategies in order to boost investments, exports and employment opportunities, but fails to develop a coherent nation branding platform at the highest strategic level. The literature review highlights the differences and relations between three concepts - place branding, nation branding and destination branding. The paper presents the results of the content analysis of key branding initiatives, followed by visual messages, developed and implemented by the Serbian Government and the National Tourism Organization of Serbia in the period from 1996 to 2016. The results are chronologically presented in the form of a discussion, establishing links between destination branding and nation branding practices in Serbia. The conclusion is that none of the branding initiatives have proved successful until now. This is predominantly due to the Government's lack of understanding of the very concept of nation branding and it being mistaken for destination branding and tourism marketing. Current promotional efforts focus on presenting Serbia to internal and external stakeholders primarily as a tourist destination.
\end{abstract}

Key words: nation branding, tourism destination, brand image, Serbia - a post-communist country.

${ }^{1}$ Corresponding author. 


\section{Introduction}

Nation branding and destination branding are highly valued and potentially conflicting processes in establishing competitiveness of a place. While attention has been paid to nation branding and destination branding individually, not much attention has been paid to how they interact. With governments experiencing increasingly formal expectations that their branding initiatives will result in a strong nation brand to promote specific economic interests of the country, we require systematic knowledge about how different branding practices play out for transitioning countries.

At the turn of the new millennium, the emergence of new nations and countries was one of the main trends that gave rise to the creation of nation branding (Yan, 2008). The emerging countries and nations saw branding as a chance to distinguish and position themselves among other newly established countries (Anholt, 2007). However, these nations were not the only ones that recognized and espoused the advantages and possibilities of branding. The world's leading nations also embraced nation branding as a tool for gaining the upper hand in the circumstances of global economic instability. Nowadays, more and more governments are turning to marketing and branding techniques to highlight competitive advantages over their closest rivals (Anholt, 2008) in order to increase investments, attract tourists, exports and talents. Originally, the core goals of branding were to acquire market share and build consumer loyalty; differentiate between previously generic products so that the producer would have control over prices and better predict the demand for certain products (Dinnie, 2008). Over time, the initial concept of branding products and services evolved and served as a basis for (tourism) destination branding, which in recent times has also been applied to places, nations and countries (Hanna and Rowley, 2010). As such, the concept of place branding has emerged, which created some additional insecurity as to what is being branded - a place, a nation, or a destination.

In order to further clarify the confusion in terminology, this study will address the following three concepts - place branding, nation branding, and destination branding. More specifically, this paper will present how these three concepts differ, whilst at the same time interrelate in case of a nation in need of rebranding due to its negative image. It is in the case of Serbia that authors wish to demonstrate how a nation engages in competitive marketing strategies with the intention to boost investments, exports and employment opportunities, but fails to develop a coherent branding platform. Hence, the chronology of branding Serbia, as a post-communist, ex-Yugoslav country, will be discussed from the perspective of nation branding and destination branding. 


\section{Place, nation, and destination: theoretical underpinnings of branding}

\subsection{Place branding}

Place branding could be defined as the process of creating place brands and network associations in the minds of the target groups "based on the visual, verbal, and behavioral expression of a place, which is embodied through the aims, communication, values, and the general culture of the place's stakeholders and the overall place design" (Zenker and Braun, 2010). Since this process is usually employed by public administration with an aim to affect perceptions of a place and create its positive image, place branding could also be considered as a "governance strategy for projecting images and managing perceptions about places" (Braun, Eshuis and Klijn, 2014:64).

For better understanding of how branding is applied to places, it is necessary to clarify the main terms that are in use and their relations. The literature on place branding suggests that the term 'place' refers to a geographic location, a nation, a country, a region, a city, and a tourism destination (Hanna and Rowley, 2010). All of these already come with a given name, and therefore the traditional branding practices of assigning a name or a symbol to a place are inapplicable. On the other hand, place branding is all about enhancing the brand image of the place (Anholt, 2010); however, "simple communications are no substitute for policies while constructing and altering the image of a country, or that a place requires more substantial efforts than graphic design, advertising or PR campaigns" (Metaxas, 2010:229). For Syssner (2010) place branding represents an element within the real ontological transformation of a place, which is observed in physical, economic, demographic or socio-cultural structural changes. Syssner (2010:37) also notes that "in the absence of structural transformations, however, place branding can lead to a change in how a place is conceptualized by different groups of actors", which is to be observed through public discourse, institutional practices and personal narratives.

Furthermore, very often terms 'nation' and 'country' are interchangeably used when referring to a practice of place branding, with a 'nation' referencing a 'country'. The 'nation' is being associated with a place or places, while the 'country' is often used for describing a geographic location. Moreover, the literature also exhibited that nations are frequently addressed as destinations, referring to nations and countries who present themselves primarily through tourism. This is because the concept of branding has been present for centuries; however, it is very difficult to precisely date its application to places - geographic locations. Szondi (2008) finds the reason for this in various nations, countries, regions and cities unknowingly applying branding throughout their history. Similarly, Anholt (2010:7) observes that places have been historically promoting their attractions and image for "making themselves famous" in order to attract investors, traders, visitors, sellers and influencers and to differentiate themselves from competitors. But it was the concept of strategic place marketing proposed by Kotler et al. (1993) that suggested for places to be run and marketed as businesses in order to adequately address technological changes and globalization 
challenges. And by applying strategic place marketing practices, marketers established places as brands in order to more easily promote and sell their products and services and thus respond to fierce competition among places, but without directly addressing the overall image and reputation of the place (Anholt, 2010; Braun, Eshuis and Klijn, 2014). This led to places being marketed through tourism and exports, with place image being tightly linked to its tourism destination image and the country-of-origin image (Kotler et al., 1999; Anholt, 2010; Martínez and Alvarez, 2010). Hence, Kotler, Asplund, Rein, and Haider (1999) note that countries often implemented the concept of place branding in unplanned and inadvertent manner, perceiving it as a tool for a destination image promotion, rather than systematically applying it in order to address the overall image of the country (Szondi, 2008).

Therefore, the most common reason for the lack of understanding of the concept of place branding is the wrong use of terms, the complexity of the influencing factors, and an unclear strategic level at which it is necessary to create and manage each of these brands. Bearing in mind that the terms 'place', 'nation' and 'destination' are also often mistaken, Freire (2005) introduced the term geo-branding and geobrands. By adopting the point of view of Freire (2005), Picture 1 presents the levels of generality, extensiveness and effects of geo-brands, from the broadest, the most general, to the most specific ones.

Picture 1

The levels of generality and extensiveness of geo-brands

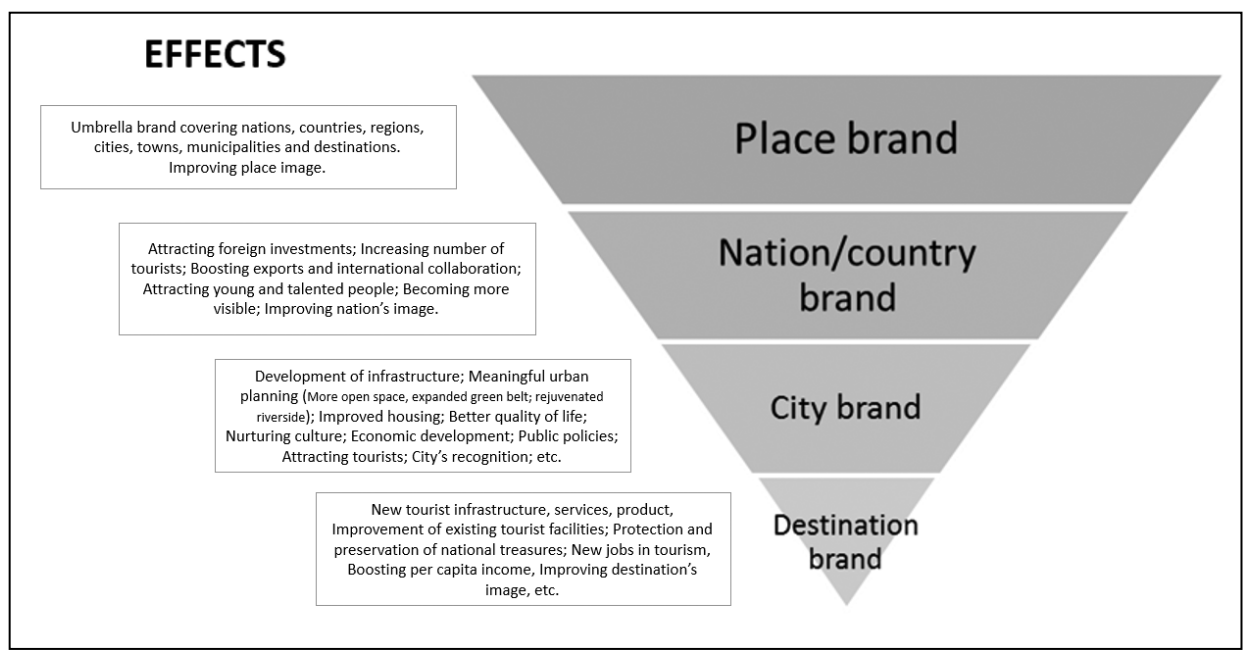

Source: Authors' own, based on literature review.

As seen from the above, place brand is the broadest and the most extensive term, while nation brand is an umbrella term which includes country, city and destination brands. Destination brand is the most specific term referring to a place only as a tourism product. Also, it is very important to understand the effects of each concept. The focus of place brand effects is primly on improving place image. On the other 
hand, nation brand can affect a wide range of segments, from investments and tourism to talents and foreigners. The focus of city branding effects is on improving the living conditions of residents and becoming more attractive to foreigners. Lastly, destination brand is so specific that it can bring improvements mainly for the purpose of tourism, especially for developing tourism infrastructure, creating tourism products and enhancing destination image. Having in mind that places are often being presented only or mostly as tourism products, the misunderstanding of terms does not come as a surprise.

\subsection{Nation branding}

Nation branding is "a process by which a nation's images can be created or altered, monitored, evaluated and proactively managed in order to enhance the country's reputation among a target international audience" (Fan, 2010:101). It can be considered a special type of place branding which numerous countries seized as a way to "boost their economies, their tourism industries, trade and foreign direct investment opportunities by pursuing a favorable image in international markets" (Bisa, 2013).

The concept of nation branding originates from the studies on country of origin, place and destination branding, public diplomacy and national identity (Fan, 2010). But it was in 1996 that Simon Anholt presented the concept of nation branding to marketing professionals. He defines it as a combination of studies on the countryof-origin topic that include political, cultural, social and historical approaches to national identity (Anholt, 2003). The author goes on to note that the nation brand, as a unique, multifaceted combination of elements, provides a basis for a nation's relevant cultural differentiation in relation to all its target audiences. The nation brand is a clear and simple measure of a country's 'license to trade' in the global market, and the acceptability of its people, hospitality, culture, policies, products, and services in the rest of the world (Anholt, 2005). But nation does not represent a product in its traditional form. In fact, nations do not offer tangible products and services, but rather consist of many factors and associations, such as a place (i.e., in geographical terms: states, cities, areas); natural resources and beauties, local products; people; history (i.e., myths, stories, landmarks, monuments); culture; language; political and economic system; social institutions; infrastructure; celebrities; design (i.e., architecture, fashion), and images (Fan, 2006). Therefore, unlike the studies on country of origin and destination branding that clearly focus on promoting specific economic interests of the country, nation branding is "concerned with a country's whole image on the international stage, covering political, economic and cultural dimensions" (Fan, 2010:98).

Furthermore, the terms 'people', 'nation' and 'country' are very often interchangeably used in the context of nation branding. This generates some confusion on whether the nation or a country is being branded and how these differ among each other. But these terms are, in fact, inseparable notions. Firstly, in the Oxford Learner's Dictionary, Hornaby (2006) defines people as a race, tribe, and group of individuals who make up a social class or nation. Secondly, Arday (2012) states that 
a nation is an institutionalized form of a people that is closely related to a country. Nation is defined as a large group of people of the same race and language (Fan, 2006), which share the same culture - a system of ideas, signs, associations, patterns of behavior and communication, but also as a group of people that recognize and accept each other as members of the same nation and origin (Gellner, 1983; Milošević Đorđević, 2003). Thirdly, in the Oxford Learner's Dictionary, country is defined as a nation occupying a particular territory and having its own government. From these three definitions, we see that those concepts are inseparable. They are intervened in a sense of relating to a group of individuals who make up a nation, institutionalized by common culture and values, and in a particular governed territory. This is why very often nation branding is synonym for country branding.

Nation branding is very often linked to public diplomacy, which Bisa (2013) sees as two associated concepts. For Bisa (2013:11), nation branding and public diplomacy "deal with communication practices that aim at influencing public attitudes and opinions as a means of impacting foreign affairs and policies as well advancing countries' economies and tourism." Depending on the context of the country, its relevant factors and target audience, developing a strong nation brand can be a very complex process. This is why countries convey unclear and confusing messages to their target audiences very often. Hence, to avoid this problem, governments need to fully grasp the concept of nation branding and get access to standardized and controlled communication (Novčić and Štavljanin, 2015). Effective nation branding "requires the nation brand executive to ensure integration and coordination of the marketing mix to reposition the new nation brand ideology and identity in the minds of stakeholders" (Amujo and Otubanjo, 2012:92). Moreover, it calls for consistency between internal and external branding strategies, "especially aligning behaviors of /all country's internal stakeholders/ through focused and strategic planning and implementation" (Amujo and Otubanjo, 2012:92). Therefore, successful creation of a strong nation brand is in developing brand ownership and in living its culture in daily scripts of top public service employees down to ordinary citizens (Urde, 1999).

\subsection{Destination branding}

Destination branding is a process of developing a unique brand identity and personality of a tourism destination that will distinguish it from competitors (Mathieson and Wall, 1982). The process refers to selecting a consistent mix of brand elements to identify and differentiate a tourism destination through positive image building (Cai, 2002). As a result of branding, a destination brand is (i) a means to differentiate a destination from its competitors, (ii) a unique look that all destination stakeholders can constantly use, and (iii) a way to communicate destination's uniqueness to tourists (Amujo and Otubanjo, 2012; Anholt, 2007; Echtner and Ritchie, 2003; Morgan, Pritchard, and Pride, 2002).

Tourism sets the stage for a very profound consumption of places, which happens at unusual times and under different conditions, because destinations represent "a unique environment and stimulation apart from those ordinary shopping settings" 
(Oh et al., 2004:309). The physical space itself is a very important factor within one's purchasing behavior (Mathieson and Wall, 1982), because it does not only represent a physical space where the consumption happens, but it is the object of consumption per se (Jančič, 1999; Urry and Larsen, 2001; Urry, 2002; Bærenholdt et al., 2004; Oh et al., 2004). Thus, tourism destination branding has gained popularity in recent years, due to tourism's rapid development into one of the most important and fastest growing economic industries worldwide, and out of forecasting trends that tourist arrivals and expenditures will significantly increase by 2030 (UNWTO, 2015).

In case of destination branding, it is extremely important to understand what is actually being branded and how this relates to place and nation branding. According to the UNWTO (2002), "local tourism destination is a physical space in which a visitor spends at least one overnight. /.../ It has physical and administrative boundaries defining its management, images and perceptions defining its market competitiveness. Local tourism destinations incorporate various stakeholders often including a host community, and can nest and network to form larger destinations." From this definition, it is evident that tourism destination is a very complex concept. Firstly, it could be defined as a geographical place, where tourists spend their free time away from their usual place of living (Jafari, 2003), which includes a village, city, island, region or country (Mundt, 2004). Secondly, in order for a place to become a tourism destination, its natural and cultural resources have to be valorized in order to meet the needs of potential and real demand (Mihalič, 2008). It has to have a developed general and tourism infra- and superstructure (Mihalič, 2008) to accommodate tourists and offer various forms of recreation. Thirdly, it has to be accessible; transportation networks, traffic connections, roads and other transportation services have to be well-developed. Fourth, its various stakeholders, their interests and the impact of tourism on host community's quality of life have to be considered when tourism development is planned and managed (Mihalič et al., 2016; Šegota, Mihalič, and Kuščer, 2016). Lastly, by the exchange theory posited by Jančič (1999:53-54), tourism destination is an exchange value: that is, a place towards which a person forms images, perceptions, attachment that on the other hand influence a person's intentions and actions.

Therefore, the focus of destination branding is on promoting economic interests of the country, or more specifically, country's economic gain from tourism. And creating a successful tourism destination brand also requires informed and fully involved participation of internal stakeholders (Šegota, Mihalič and Kuščer, 2016) from government officials down to local residents, that are willing to deliver promised tourism experiences (Jančič, 1999). Despite efforts for positive destination and nation brand development, very often political and social instability, war, natural disasters etc. result in negative nation brand identity (Amujo and Otubanjo, 2012), which will reflect in the negative brand image of a destination. 


\subsection{Nation and destination image}

Branding a place, nation and destination results in creating an image of what is being branded. Governments' aim is to create strong brands with positive images that will bring various economic benefits to the country. Thus, brands are being developed and created by governments or other official entities, but brand images are the sums of beliefs and impressions in the minds of target audiences (Kotler and Gertner, 2002).

Martínez and Alvarez (2010:749) observe that nation image and destination image are interrelated "due to the influence of the former on the perceptions regarding the products of that country, including tourism products." The interrelatedness of nation and destination image originates from the four main common characteristics of the two concepts: complexity, multidimensionality, relativity, and dynamic nature (Beerli and Martín, 2004; Martínez and Alvarez, 2010). Nation and destination image are two very complex constructs. As seen from the above, the main challenge for both nation and destination branding is how to communicate a single image to different target audiences and get all stakeholders to convey the same messages about a place. Moreover, image is not only a sum of beliefs and impressions, but it also has an emotional component (Crompton, 1979; Moutinho, 1987; Baloglu and McCleary, 1999). Beliefs and opinions represent a cognitive dimension of the image, while affects and emotions are elements of its affective dimension (Kim and Richardson, 2003; Pike and Ryan, 2004). Both of these components contribute to the formation of an overall image about a place (Lin et al., 2007; San Martín and Rodríguez del Bosque, 2008), with some researchers strongly suggesting that its affective component has more effect on the overall image over its cognitive component (Beerli Palacio, Díaz Meneses and Pérez Pérez, 2002; Beerli and Martín, 2004). Image is very relative and dynamic, because it is based on subjective assessments which are subject to changes over time and based on past experience (Crompton, 1979; Gartner, 1986; Chon, 1991; Tasci, Gartner and Cavusgil, 2007). Brezovec (2001) observes that nation and destination image are in a reflective-constructive relationship. Author stresses out that nation image influences the perception of tourism product attributes of the country and nation image is thus reflected in the destination image. Furthermore, knowledge and perceptions on tourism products, either strongly positive or negative, influence perceptions of the nation and thus destination image constructs nation image. Others similarly observe that nation image has a strong influence on travel behavior (i.e. intention to visit, intention to re-visit, and recommending the destination). Nadeau et al. (2008) point that personal experience with a destination may also impact how nation is being perceived by changing stereotypes into more accurate perceptions of the nation.

However, the fundamental distinction between nation and destination image is "in the former representing a combination of various generic associations, independent of a particular context, while the latter refers to the tourist's perspective and may indicate a specific area, a city, a region or a country" (Martínez and Alvarez, 2010: 751). Martinez and Alvarez (2010) also acknowledge that there is a fundamental distinction in how nation image and destination image are formed. One's image 
about the nation is influenced by various types of information accumulated over time which include, but are not limited to, historical events, political, economic and cultural processes and transformations, and even through exports connected to the country of origin effects (Roth and Diamantopoulos, 2009; Martínez and Alvarez, 2010). On the other hand, different kinds of information may become relevant for destination image formation. Videos, photos, brochures, articles and reviews of a destination that are part of institutional tourism promotional activities, will lead to creation of certain destination image and develop personal impressions about the destination (Gallarza, Saura and Garcia, 2002). This is why perceptions created through tourism cannot entirely cover nation image in direct foreign investments, talent acquisition and made in effect. The latter are subject to political and economic contexts of the country which may be distinctively different from its tourism context. For example, Martinez and Alvarez (2010) demonstrated that Turkey had a negative nation image and a positive destination image. That is, as a country it is perceived as "insecure, dangerous, or having negative connotations as a 'Third World' country, while it may also be appealing from a tourism point of view due to its historical or cultural resources, or to its exotic way of life, which might be attractive to the potential tourist" (Martínez and Alvarez, 2010:759).

\section{Politics, conflicts and image of a place}

Place image may be affected by many events beyond its control. Negative events, such as political conflicts, diseases, terrorism or insecurity, were shown to have negative influence on place image (Gertner and Kotler, 2004; Alvarez and Campo, 2014). This is mainly due to publicity that arouses around the negative events which very often have media coverage worldwide. Moreover, violence, political conflicts, war and terrorism represent a real threat to country image (Gertner and Kotler, 2004). In that case, time and strategic image management are two essentials in overcoming the negative image of a place (Gertner and Kotler, 2004; Alvarez and Campo, 2014).

\subsection{Countries in transition and their image}

For more than 20 years, the new states have been investing wide-ranging and complex efforts to position themselves on the geographic and mental map of Europe, but also to present themselves to the world as democratic and politically stable countries with developing economies (Szondi, 2007). They took on the path of transition from a centralized to a market economy, from an authoritarian, one-party system to a multi-party, democratic society, including the systemic change of nations' identity and image. Aronczyk (2008) notes that transition countries were focused on internal problems, and only several years into transition, they started realizing and becoming aware of the importance of their image among external stakeholders.

Leading authors in the field of nation branding agree that countries of Central and Eastern Europe constitute a fertile ground for research on the undertaken nation 
branding efforts (Anholt, 2007, 2010, 2013; Aronczyk, 2008; Hall, 2002; Kanaeva, 2012; Szondi, 2007), because of their similar geographical, economic, political, and social systems, and historical roots. Moreover, nation branding initiatives in certain countries of Central and Eastern Europe, such as Poland, Slovenia, Latvia, Bulgaria, Yugoslavia, have been a subject to analysis by academic researchers and practitioners (Endzina and Luneva, 2004; Florek, 2005; Hall, 2002; Kanaeva, 2012; Konecnik and Go, 2007; Poljanec-Borić, 2016), but without historical and socio-cultural transformation contexts in place. In that case, political turmoil that has evolved at the beginning of the $20^{\text {th }}$ century, influenced how Central and Eastern European countries are perceived today. In many cases, political instability significant for the transitional countries that emerged in the early 90s resulted from the events that were beyond their control. In the case of Yugoslavia, many of its former countries have been influenced by political and territorial conflicts, and therefore had and some still have negative image.

\subsection{Yugoslavia: from its origins to its downfall}

The analysis of branding of any former Yugoslav state, which emerged as a new nation in the late $20^{\text {th }}$ century, and its efforts of creating a recognizable image and identity, is unimaginable without introducing its Yugoslav roots. Firstly, the Kingdom of Yugoslavia - the Kingdom of Serbs, Croats and Slovenes, emerged in the territory of the Balkans, on the remnants of the Ottoman and Austro-Hungarian Empires in December of 1918 (Petranović, 1988). As such, it united South Slavs and other non-Slav communities, Orthodox believers, Catholics, Muslims, and members of different cultures (Hall, 2002; Šegota, 2015; Novčić and Štavljanin, 2015) under the Serbian dynasty of Karađorđević. Its geographical position at the crossroads of the East and West ensured favorable conditions for economic development and overall progress.

After the World War II, there was a change in the form of government, the monarchy and the Kingdom of Yugoslavia ceased to exist. With Josip Broz Tito at the helm, there emerged the Federal People's Republic of Yugoslavia (hereinafter FPRY), which was soon after renamed to the Socialist Federal Republic of Yugoslavia (hereinafter SFRY) in the 1963 Constitution (Petranović, 1988). This newly formed state consisted of six republics: Slovenia, Croatia, Bosnia and Herzegovina, Serbia, Montenegro and Macedonia. With the change of the state entity political regime, a new ideology was introduced: socialism. The new social and economic system based on socialism and communism was directly reflected in changes in social values, customs, myths, patterns of behavior that were considered socially acceptable (Novčić and Štavljanin, 2015). The building of Yugoslav identity took on several forms, but "it is a fact that Tito played a crucial part in it" (Šegota and Jančič, 2013). It is during his lifetime that he managed to develop a unity of different nations, which was mostly expressed through the Yugoslav education system, music and sports, in which different ethnicities were unified under the nation of Yugoslavia (Šegota and Jančič, 2013; Volcic, 2009). 
However, a decade after Tito passed away, in 1991 the majority of Yugoslav republics decided to part their ways and to seek independence. This erupted into the political and territorial conflict among the former republics which gained negative worldwide publicity and created consequential negative images about the whole region. During this turmoil, defining the new identity gained in importance in all newly formed and independent nations. Many of them recognized tourism as an opportunity for positioning the country on the world's tourism market stage (Šegota and Jančič, 2013). By focusing on destination branding, the nation branding was not in their strategic focus, with the priority not being given to the important problems at a national level. As a consequence of the one-sided approach to nation branding through tourism, most former Yugoslav countries are still unrecognizable on the world's stage investmentwise, export-wise, and employment-wise. However, Slovenia is an exception to the case, since development and communication of its competitive identity has been strategically aligned with its political transition into an independent and democratic nation. In 2007, Slovenia established its most successful nation brand 'I feel Slovenia' which has since been relevant across its political, cultural, tourism and sports areas (Poljanec-Borić, 2016). This new competitive Slovenian identity signaled that its "marketing experts and political stakeholders decided to stabilize the nation brand and to define a competitive identity of a nation in global context" (Poljanec-Borić, 2016:13).

Since 1991, contrary to other former Yugoslav countries, Serbia changed its name several times: it was part of the Federal Republic of Yugoslavia and the State Union of Serbia and Montenegro (Popesku, Damnjanović, Novčić, and Premović, 2010). It was only in 2006 that the National Assembly declared the independence of the Republic of Serbia. Thus, the newly-formed country of Serbia restored its name which was last time used during the time of the Kingdom of Serbia. It has simultaneously launched the process of seeking the identity of the nation, which was subordinate to the identity of the bigger community in the time of Yugoslavia (Novčić, Damnjanović, and Popesku, 2012). Similar to other former Yugoslav countries, the challenges of developing and positioning the nation brand, and improving its image and reputation emerged soon after.

\section{The method}

Case study approach was utilized for gaining insights into nation branding and destination branding practices in Serbia. The approach was based on the review of secondary literature and interviews the authors undertook with official representatives of National Tourism Organization of Serbia (hereinafter NTOS). The data were collected from 2014 to 2016 with the help of NTOS representatives and were derived from various governmental documents, Internet sources, books and magazines, archived brochures and texts. Since logo and a brand slogan are two most distinct elements of brand identity (Kotler, 2000; Poljanec-Borić, 2016), tourism campaigns with key visual messages developed and published by NTOS in the period from 1996 to 2016 were identified and analyzed. The results of the analysis are presented in form of a discussion, establishing the links between nation branding and destination branding practices in Serbia. 


\section{Discussion}

\subsection{The case of (re)branding Serbia: from destination to nation}

The journey towards an independent Serbia was marked by dynamic, historical, political and economic changes, ranging from political and territorial conflicts, international sanctions and NATO bombing. These events significantly contributed to the creation of its negative image (The Economist, 2006; Kanaeva, 2012; Nation branding, 2009). Although it may seem that the majority of negative associations linked to the nations involved in the conflicts disappeared with the Federal Republic of Yugoslavia, some associations still continued to haunt Serbia in particular. Apart from the significantly deteriorated image, its nation was poorly recognized or even unrecognized internationally due to its recent reinstatement of the former name of Serbia.

Additionally, its bigger problem was that its internal stakeholders - its citizens - had a rather unclear, inconsistent and somewhat confusing perceptions of Serbian identity (Popesku et al., 2010). With this problem at its doorsteps, seeking its somewhat forgotten identity and improving its deteriorated nation image meant a departure from the legacy of the past - Yugoslavia, and a return to its roots, history, culture and traditions. Hall (2002) notes that in the 90s, the ethnic identity was used as a tool for seeking the national identity of Serbia, very often with a political purpose. Hall (2002) further observes that the historical legacy was actually the main source and constituent element of the forgotten identity of the Serbian nation. The first initiatives on this topic emerged with the recognition of the importance of a strategic approach to nation branding.

\subsubsection{Serbia: Landscape painted from the heart}

In late 90s, the NTOS presented the first official tourism campaign with the slogan Serbia: Landscape painted from the heart (see Picture 2). The key elements of the ethnic identity were woven into the presentation of the Serbian tourism and the term 'landscape' was explained through nature and culture (NTOS, 2000). Besides the landscape, an emphasis was also placed on the Serbian, Orthodox tradition, while cultures and traditions of other communities were presented only symbolically (Hall, 2002). It was in this first official tourism campaign that the government seized the opportunity to initiate the complex process of nation branding by developing initiatives in the field of tourism for presenting Serbia as an attractive tourism destination (Novčić and Štavljanin, 2015). 
Picture 2

Key visual elements of Serbian tourism marketing campaigns (1996-2012)

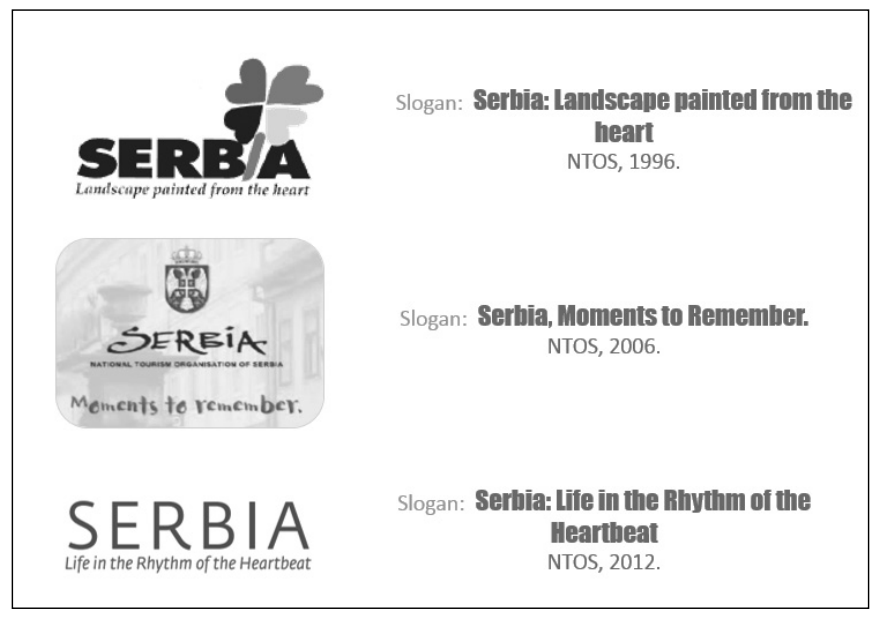

Source: NTOS (2000; 2007; 2014).

Therefore, similar to other former Yugoslav countries, Serbia initiated its nation branding through destination branding. This points towards the existing recognition of the importance of nation branding, but also towards the lack of understanding of how it differs from destination branding. As if "image improvement, rather than real improvement, is too often used as a panacea or quick fix for a place's problems" (Gertner and Kotler, 2004: 54). And Serbia was no exception to the latter, since besieged by negative image, the government was apparently in need of a new image which was delivered through destination image. However, "one slogan, one campaign, no matter how clever or creative, cannot sell everything to everyone" (Fan, 2010: 102), which only confirms that the nature and culture do not have the ability to position Serbia in the marketplace in terms of investment, employment and export.

However, the change of the political regime at the start of the new millennium brought about a shift in the direction of nation branding. Firstly, in 2000, the new state administration hired the advertising agency Saatchi and Saatchi, with the idea of creating a new tourism campaign. Presenting Serbia as a multi-ethnic country (Popesku and Marić, 2003) represented the backbone of the campaign. The changes in the strategic orientation in rebranding Serbia are evidenced in the following sentences (NTOS, 2000): "Serbia is the meeting place of cultures, religions and languages. Although more than forty different nations live in Serbia, they do have some things in common - their homes are wide open to friends." This is meant to represent Serbia as a home of various nations, with heart-warming welcome to the world, opposite to its rather negative image developed due to the socio-political turmoil in the 90s. Secondly, during the early 2000's, the new state administration invested considerable efforts into improving Serbia's image, strengthening the position of the country and nation among the Western European countries and attracting foreign investments (Hall, 2002). The efforts resulted in the first systematically conceived 
and strategically created initiative on nation branding at a national level, aiming at improving Serbia's image in the world and building its nation brand. But it was not until 2006 that the government and the Ministry of Foreign Economic Relations released an international tender looking for consultancy on improving nation image and creating a nation branding platform (The Economist, 2006; Kanaeva, 2012). This initiative resulted in establishing a state body called the Council for the Promotion of Serbia, colloquially known as the Council for the Branding of Serbia (hereinafter the Council). The main goal of the Council was to develop the National Strategy for the Promotion of Serbia that would later be adopted by the Government of Serbia on all nation brand levels.

It is with this initiative that the government recognized the importance of nation branding and prioritized nation image over its destination image. The establishment of the Council clearly demonstrates that nation branding was conceptualized as meaningful, practical and important for promoting the economic and political interests of Serbia, which is then to be measured and implemented at its nation brand sublevels (i.e. destination brand, event brand, export brand, etc.).

\subsubsection{Sights and sounds of Serbia: Moments to remember}

In cooperation with the NTOS, the Council and the Ministry of Trade and Tourism launched a new campaign to promote Serbia in 2007. The promotion took place under the slogan Sights and sounds of Serbia as part of the wider campaign named Moments to remember (NTOS, 2007). So, regardless of the initial beliefs that nation branding would be the driving force of all other branding processes, the Government's official rationale for such a promotion was in "the advertising campaign promoting Serbia at a local and global level aiming at attracting tourists, as well as foreign investors" (Vlada Republike Srbije, 2007). And yet again, nation branding managed to fall under destination branding.

Soon after the official screening of yet another destination branding campaign aimed at promoting the country's investment economic interests, the work of the Council was affiliated with many controversies (Kanaeva, 2012). These partly stemmed from the inadequate communication of the basic information related to its mission and the expected outcomes. Although the Council launched several concrete initiatives such as the organization and hosting of the two mega events, i.e., the Eurovision Song Contest 2008 and the Summer Universiade 2009, the undertaken efforts had a short-term effect (Kanaeva, 2012). The media and political turmoil in relation to the Council's work led to a general public animosity towards the Council and the entire nation branding concept. Consequently, the Council was dismantled soon after. Nonetheless, the government's focus was yet again shifted from the importance of developing a strong nation brand that would set the strategic framework for promoting Serbia as an attractive country in terms of investments, exports and employment. 


\subsubsection{Life in the rhythm of the heartbeat}

Following the media backlash and internal stakeholders' animosity towards the Council, the government placed NTOS in charge of nation branding initiatives. Unsurprisingly, these were developed by focusing primarily on enhancing Serbia's destination image. Thus, in 2014, a new tourism campaign was launched under the slogan Life in the rhythm of the heartbeat. It aimed at describing Serbia as a country in Southeast Europe, at the center of the Balkan Peninsula "connecting the East and West for centuries - a land in which civilizations, cultures, faiths, climates and landscapes meet and mingle" (NTOS, 2014). The campaign has placed emotional attributes at the core of branding Serbia, serving as a trigger for positive emotions and affirmative associations to Serbia as a tourism destination.

Putting the NTOS in charge of nation branding was a strategic move on the part of the government to overcome the media backlash and animosity surrounding the Council. Predictively, the nation brand once again was put under the destination brand which does not possess the power to create positive place image investmentwise, export-wise, and employment-wise (Gertner and Kotler, 2004; Fan, 2010; Martínez and Alvarez, 2010). However, if strategically managed and consistent in its messages, destination image could have been strong enough to pave the way for positioning Serbia on a tourism map and thus changing its deteriorated image.

\subsection{Serbia for internal and external stakeholders}

By acknowledging that internal stakeholders still did not have a clear perception of Serbia's national identity, in 2015 NTOS decided to divide its efforts in promoting Serbia separately to internal and external stakeholders. Thus, we observe two parallel campaigns actively being implemented with the goal to improve Serbia's image and attract tourists (see Picture 3). The campaign named My Serbia was targeting domestic tourists in order to increase visitations during summer months (from June to September). The campaign was implemented in collaboration with the Ministry of Trade, Tourism and Telecommunication of the Republic of Serbia in order to stimulate domestic tourists to spend their holidays in Serbia instead of traveling abroad. The initiative for internal stakeholders also included the so-called subsidization of holidays, where members of specific social groups in Serbia could have been granted a voucher for lower-priced holidays in Serbia (Moja Srbija, 2016).

Further, the slogan My Serbia aimed at communicating national pride and patriotism among internal stakeholders - Serbian citizens. By using the first-person possessive pronoun 'my', it aimed at influencing the affective image component, which was shown to have significant influence on the overall image when compared to the cognitive image component (Beerli Palacio, Díaz Meneses and Pérez Pérez, 2002; Beerli and Martín, 2004). Moreover, even though the brand was primarily used for destination branding purposes, the use of the first-person pronoun determines one's belonging to Serbia or possibility to tie one's association to Serbian national identity. 
In this case, destination brand can further strategically evolve into a place brand, event brand, investment brand or trade brand for the purpose of communicating with internal stakeholders.

Picture 3

Visual elements of internal and external tourism promotion campaigns My Serbia
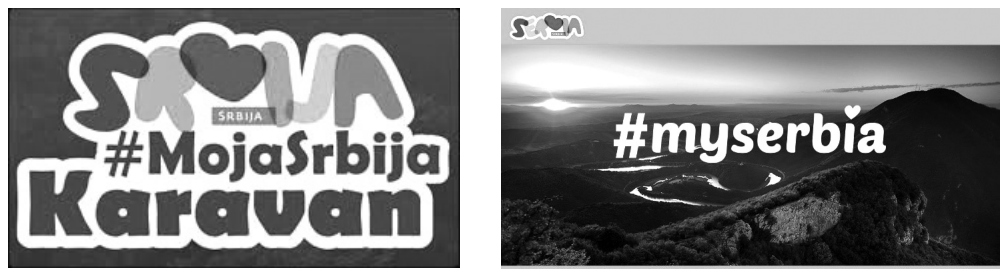

Source: NTOS $(2016 ; 2017)$.

On the other hand, the river Danube and water resources of the country were chosen as the main features for tourism promotion among external stakeholders (NTOS, 2017). Thus, the focus of separately launched promotional campaign is on highlighting Danube as a unique tourism destination which flows through Serbia along 588 kilometers and yet as the biggest European river that connects countries and nations (NTOS, 2017). The slogan of the campaign was The Damube in Serbia: 588 impressions, underlining the word 'impressions' and directly relating it to experiences one could have when visiting Serbia. A promotional video with the same title followed, successfully capturing the details of a river that connects 10 countries, over 100 million people, presenting Danube on its path through Serbia as a variety of landscapes, cultural heritage, archaeological sites, lifestyles, and events (NTOS, 2017). Further, Danube is presented in the video in a human-like form, using it to narrate the story with the sole purpose to establish a personal connection with viewers, evoke emotions and deliver a strong message: "I have many different names, I have many life forms, and many faces, I am the witness of ages, I am constant, and yet I'm changing, I am the thread that connects us all" (NTOS, 2014).

Using the Danube as a narrator of the Serbian story, we witness the use of anthropomorphism at its best. NTOS used imbuing of objects with human personal characteristics, which enabled people to think of objects as humans, and thus easily relate their own self (Epley et al. 2007; Gurthrie 1993; Luthar and Luthar 2007). In order to emphasize their uniqueness, many destinations had to 'move away' from promoting their functional attributes (beaches, beautiful scenery, and friendly places) (Ekinci, Sirakaya-Turk, and Baloglu, 2007; Piggott et al., 2004; Murphy, Benckendorff, and Moscardo, 2007), and start creating unique personalities through metaphors that would craft a unique relationship between places and tourists (Ekinci and Hosany, 2006). Thus, NTOS successfully used anthropomorphism, personification techniques, in order to create user imagery of Serbia based on distinct personality characteristics. By applying the following techniques, a destination such as Serbia can differentiate itself among competitors, create consumer preferences and usage, and market a destination across cultures (Aaker, 1997; Ekinci and Hosany, 2006). 
In short, NTOS centered its recent marketing and promotional activities on Serbia's destination brand personality.

Moreover, having used Danube to narrate the story of changes, flows, transitions, and yet of history and steadiness, NTOS managed to capture the changing nature of Serbia as a country. Yet, it seems as if the Danube narrates the story of a changing nation, being part of many different political systems; however, always present in its national identity, tradition, culture and history. Again, this destination brand and its narration still do not have the potential to externally communicate the economic interests of the country. But, they create the opportunity for changing the image of Serbia that has accumulated lots of negativity in its transition from the former Yugoslav nation to independent Serbia known today.

\section{Conclusion}

The umbrella concept of place branding encompasses nation branding and destination branding, the two distinct, yet interrelated concepts. It is their interrelatedness that very often causes the problem for the governmental bodies to fully develop strong nation brands, together with strong destination brands. In conclusion, nation branding is a process of creating positive image of a nation investment-wise, exportwise, employment-wise, and tourist-wise, whilst destination branding is primarily focused on creating a positive image among tourists. It is not to say that these two concepts do not go hand in hand, on the contrary: very often it is the destination brand that is perceived as the means to convey a country's positive image thus disregarding the influence of the nation brand. And Serbia is no exception to the latter.

In order to inform on the nation branding and destination branding practices, we analyzed the content of branding campaigns of Serbia in the period from 1996 to 2016. It was demonstrated that since gaining independence, Serbia has recognized the importance of the implementation of the nation branding concept. Moreover, the Government systemically approached the development of a strategic framework, national strategy and platform at a national level, aimed at creating a strong nation brand that would reposition the country and alter its deteriorated image. However, this has not proven to bring positive results, since Serbia's nation brand always falls under its destination brand, which is similar to Popesku and Marićs (2003) conclusion that no nation branding initiative to this date has proved to be successful. This is predominately due to the lack of understanding of the very concept of nation branding and it being mistaken for the process of destination branding for tourism purposes. Today, the promotion of Serbia boils down to presenting the country primarily as a tourism destination. The main generator for the majority of promotional activities in improving the deteriorated image of Serbia is its National Tourism Organization, which is nowadays focusing its efforts on communicating with internal and external stakeholders using different, but consistent messages which would help trigger positive emotions and affirmative images of Serbia as a destination brand. These, however, create the opportunity for developing a nation brand with strong messages for internal and external stakeholders. 
By witnessing the case of Serbia and its government's struggle to distinguish between nation and destination branding, many countries with deteriorated, negative, neutral or even confusing image could follow the example by (i) developing two separate destination branding platforms for external and internal stakeholders, (ii) developing strong emotional messages aimed at influencing affective image formation component, and (iii) creating foundations for nation branding in strategically managed destination branding.

\section{References}

1. Aaker, J. L. (1997). Dimensions of brand personality. Journal of Marketing Research, 34 (3): 347-356.

2. Alvarez, M. D. and Campo, S. (2014). The influence of political conflicts on country image and intention to visit: A study of Israel's image. Tourism Management, 40: 70-78.

3. Amujo, O. C. and Otubanjo, O. (2012). Leveraging Rebranding of "Unattractive" Nation Brands to Stimulate Post-Disaster Tourism. Tourist Studies, 12(1): 87-105.

4. Anholt, S. (2003). Brand New Justice: The upside of global branding. Oxford, UK: Elsevier Butterworth-Heinemann.

5. Anholt, S. (2005). Plug into Your National Brand. International Trade Forum Magazine, 20-23.

6. Anholt, S. (2007). Competitive identity: The new brand management for nations, cities and regions. New York: Palgrave Macmillan.

7. Anholt, S. (2008). From nation branding to competitive identity-The role of brand management as a component of national policy, in: Dinnie, K. (Ed.). $\mathrm{Na}$ tion Branding: Concepts, Issues, Practice (pp. 22-23). Oxford, UK: Butterworth Heinemann Dutton.

8. Anholt, S. (2010). Definitions of place branding - Working towards a resolution. Place Branding and Public Diplomacy, 6 (1): 1-10.

9. Anholt, S. (2013). Beyond the Nation Brand: The Role of Image and Identity in International Relations. Exchange: The Journal of Public Diplomacy, 2 (1): 6-12.

10. Anholt, S. (2014). Public Speaking, past events attended by authors.

11. Arday, L. (2012). Narod, nacija, država, nacionalna država, nacionalizam. Psibologija, 3 (4): 1-4.

12. Aronczyk, M. (2008). Living the Brand: Nationality, Globality and the Identity Strategies of Nation Branding Consultants 1. International Journal of Communication, 2: 41-65.

13. Bærenholdt, J. O.; Haldrup, M.; Larsen, J.; Urry, J. (2004). Performing Tourist Places. Burlington, Hants: Ashgate Publishing Company.

14. Baloglu, S. and McCleary, K. W. (1999). A model of destination image formation. Annals of Tourism Research, 26 (4): 868-897.

15. Beerli Palacio, A.; Díaz Meneses, G. and Pérez Pérez, P. J. (2002). The configuration of the university image and its relationship with the satisfaction of students. Journal of Educational Administration, 40 (5): 486-505.

16. Beerli, A. and Martín, J. D. (2004). Factors influencing destination image. Annals of Tourism Research, 31 (3): 657-681. 
17. Bisa, S. (2013). Rebranding Greece: Why Nation Branding Matters. Exchange: The Journal of Public Diplomacy, 4 (1): 61-68.

18. Braun, E.; Eshuis, J. and Klijn, E. H. (2014). The effectiveness of place brand communication. Cities, 41: 64-70.

19. Brezovec, A. (2001). Imidž države kot turistične destinacije. Teorija in praksa, 38 (4): 739-754.

20. Cai, L. A. (2002). Cooperative branding for rural destinations. Annals of Tourism Research, 29 (3): 720-742.

21. Chon, K.-S. (1991). Tourism destination image modification process: Marketing implications. Tourism Management, 12 (1): 68-72.

22. Crompton, J. L. (1979). Motivations for pleasure vacation. Annals of Tourism Research, 6 (4): 408-424.

23. Dinnie, K. (2008). Nation branding: Concepts, issues, practice. Oxford, UK: Butterworth Heinemann Dutton.

24. Echtner, C. M., and Ritchie, J. R. B. (2003). The Meaning and Measurement of Destination Image. The Journal of Tourism Studies, 14 (1): 37-48.

25. Ekinci, Y., and Hosany, S. (2006). Destination Personality: An Application of Brand Personality to Tourism Destinations. Journal of Travel Research, 45: 127139.

26. Ekinci, Y.; Sirakaya-Turk, E. and Baloglu, S. (2007). Host image and destination personality. Tourism Analysis, 12(5-6): 433-446.

27. Endzina, I., and Luneva, L. (2004). Development of a national branding strategy: The case of Latvia. Place Branding and Public Diplomacy, 1 (1): 94-105.

28. Epley, N.; Waytz, A. and Cacciopoo, John T. (2007). On Seeing Human: A ThreeFactor Theory of Anthropomorphism. Psychological Review, 114 (4): 864-886.

29. Fan, Y. (2006). Branding the nation: What is being branded? Journal of Vacation Marketing, 12 (1): 5-14.

30. Fan, Y. (2010). Branding the Nation: Towards a Better Understanding. Place Branding and Public Diplomacy, 6 (2): 97-103.

31. Florek, M. (2005). The country brand as a new challenge for Poland. Place Branding and Public Diplomacy, 1 (2): 205-214.

32. Freire, J. (2005). Geo-branding, are we talking nonsense? A theoretical reflection on brands applied to places. Place Branding, 1: 347-362.

33. Gallarza, M. G., Saura, I. G. \& García, H. C. (2002). Destination image: towards a conceptual framework. Annals of Tourism Research, 29(1): 56-78.

34. Gartner, W. C. (1986). Temporal influences on image change. Annals of Tourism Research, 13 (4): 635-644.

35. Gellner, E. (1983). Nations and Nationalism. Ithaca, New York. New York: Ithaca.

36. Gertner, D. and Kotler, P. (2004). How can a place correct a negative image? Place Branding, 1 (1): 50-57.

37. Gurthrie, S. E. (1993). Face in the Clouds: A New Theory of Religion. Oxford: Oxford University Press.

38. Hall, D. (2002). Brand development, tourism and national identity: The re-imaging of former Yugoslavia. Journal of Brand Management, 9 (4): 323-334.

39. Hanna, S., and Rowley, J. (2010). An analysis of terminology use in place branding. Place Branding and Public Diplomacy, 4 (1): 61-75. 
40. Hornaby, A. S. (2006). The Advanced Learner's Dictionary of Current English.

41. Jafari, J. (ed.) (2003). Encyclopedia of tourism. London, New York: Routledge

42. Jančič, Z. (1999). Celostni marketing (Integrated marketing). Ljubljana, Slovenia: Faculty of Social Sciences UL.

43. Kanaeva, N. (2012). Branding Post-Communist Nations Marketizing National Identities in the New Europe. New York: Routledge.

44. Kim, H. and Richardson, S. L. (2003). Motion picture impacts on destination images. Annals of Tourism Research, 30 (1): 216-237.

45. Konecnik, M., and Go, F. (2007). Tourism destination brand identity: The case of Slovenia. Journal of Brand Management, 15 (3): 177-189.

46. Kotler, P.; Asplund, C.; Rein, I. and Haider, D. (1999). Marketing Places - Europe. Financial Times. Harlow: Pearson Education.

47. Kotler, P.; Haider, D. H. and Rein, I. (1993). Marketing Places: Attracting Investment, Industry and Tourism to Cities, States and Nations. New York: Free Press.

48. Kotler, P. and Gertner, D. (2002). Country as brand, product, and beyond: A place marketing and brand management perspective. Journal of Brand Management, 9 (4/5): 249-261.

49. Lin, C.-H.; Morais, D. B.; Kerstetter, D. L.; Hou, J.-S. (2007). Examining the Role of Cognitive and Affective Image in Predicting Choice Across Natural, Developed, and Theme-Park Destinations. Journal of Travel Research, 46 (2): 183-194.

50. Luthar, O. and Luthar, B. 2007. Trio za orkestar. Resničnost, pripoved in pomen. [Trio for an orchestra. Validation, narrative and measning.]. Filozofski vestnik 28 (1): 103-119.

51. Martínez, S. C. and Alvarez, M. D. (2010). Country Versus Destination Image in a Developing Country. Journal of Travel \& Tourism Marketing, 27 (7): 748-764.

52. Mathieson, A., and Wall, G. (1982). Tourism Economic, Physical and Social Impacts. London: Longman.

53. Metaxas, T. (2010). Place marketing, place branding and foreign direct investments: Defining their relationship in the frame of local economic development process. Place Branding and Public Diplomacy, 6 (3): 228-243.

54. Mihalič, T. (2008). Turizem: Ekonomski vidiki [Tourism. Economic Issues]. Ljubljana: Ekonomska fakulteta Univerze v Ljubljani.

55. Mihalič, T.; Šegota, T.; Cvelbar, L. K.; Kuščer, K. (2016). The influence of the political environment and destination governance on sustainable tourism development: a study of Bled, Slovenia. Journal of Sustainable Tourism 204 (11): 1489-1505.

56. Milošević Đorđević, J. (2003). Jedan pokušaj klasifikacije teorijskih razmatranja nacionalnog identiteta. Psihologija, 36 (2): 125-140.

57. Моја Srbija. (2016). Обавештење за подношење пријава за доделу ваучера. Retrieved January 13, 2017. (http://www.serbia.travel/home.779.html).

58. Morgan, N.; Pritchard, A. and Pride, R. (eds.) (2002). Destination Branding: Creating the Unique Destination Proposition. Oxford, UK: Butterworth-Heinemann.

59. Moutinho, L. (1987). Consumer behaviour in tourism. European Journal of Marketing, 21 (10): 5-44.

60. Mundt, J. W. (2004). The branding of myths and the myths of branding: Critical remarks on the »branding " of destinations, in: Weber, S. and Tomljenović, R. (Eds.). Reinventing a Tourism Destination: Facing the Challenge, pp. 43-55. Zagreb: Institute for Tourism Zagreb. 
61. Murphy, L.; Benckendorff, P. and Moscardo, G. (2007). Linking Travel Motivation, Tourist Self-Image and Destination Brand Personality. Journal of Travel $\&$ Tourism Marketing, 22 (2): 45-59.

62. Nadeau, J.; Heslop, L.; O'Reilly, N.; Luk, P. (2008). Destination in a country image context. Annals of Tourism Research, 35 (1): 84-106.

63. Nation branding. (2009). Country branding consultant Jose Filipe Torres on branding Serbia. Nation Branding, 2-4.

64. Novčić, B. and Štavljanin, V. (2015). Brendiranje nacije: Analiza brend identiteta Srbije. Časopis Marketing, 46 (4): 263-275.

65. Novčić, B.; Damnjanović, V. and Popesku, M. (2012). Serbia Brand Identity: Perspectives of Residents and Diaspora. EuroMed Journal of Business, 7 (3): 256-267.

66. NTOS. (1996). Serbia - Landscape painted from the heart. Belgrade.

67. NTOS. (2000). Landscape painted from the heart. Belgrade.

68. NTOS. (2007). Serbia: moments to remember. Belgrade.

69. NTOS. (2014). Serbia: life in the rhythm of the heartbeat. Belgrade.

70. NTOS. (2016). Ponovo kreće promotivni karavan "Moja Srbija".

71. NTOS. (2017). Film TOS-a "Dunav u Srbiji - 588 utisaka" jedan od najboljih na svetu.

72. Oh, J. Y-J.; Cheng, C-K.; Lehto, X. Y.; O'Leary, J. T. (2004). Predictors of tourists' shopping behaviour: Examination of socio-demographic characteristics and trip typologies. Journal of Vacation Marketing, 10 (4): 308-319.

73. Petranović, B. (1988). Istorija Jugoslavije 1918-1988, knjiga I - Kraljevina Jugoslavija 1914-1941. Beograd: Nolit.

74. Piggott, R.; Morgan, N. J. and Pritchard, A. (2004). New Zealand and The Lord of the Rings: leveraging public and media relations, in: Morgan, N. J.; Pritchard, A. and Pride, R. (Eds.). Destination Branding ( $2^{\text {nd }}$ Edition, pp. 207-225). Burlington, MA: Elsevier.

75. Pike, S. and Ryan, C. (2004). Destination Positioning Analysis through a Comparison of Cognitive, Affective, and Conative Perceptions. Journal of Travel Research, 42 (4): 333-342.

76. Poljanec-Borić, S. (2016). Destination Brand Management for the Support of Political Identity: The Case of Slovenia. Sociology \& Space, 54 (1), 3-18.

77. Popesku, J., and Marić, R. (2003). Ecotourism Development as a Tool for Repositiong, in: International Scientific Conference the Development and Potentials of Ecotourism on Balkan Peninsula'. Pirot, Serbia.

78. Popesku, M.; Damnjanović, V.; Novčić, B.; Peremović, M. (2010). Serbia as Brand - Internal Perspective, in: $3^{\text {rd }}$ Annual EuroMed Conference of the EuroMed Academy of Business, Business Development Across Countries and Cultures. Nicosia, Cyprus.

79. Roth, K. P. and Diamantopoulos, A. (2009). Advancing the country image construct. Journal of Business Research, 62 (7): 726-740.

80. San Martín, H. and Rodríguez del Bosque, I. A. (2008). Exploring the cognitiveaffective nature of destination image and the role of psychological factors in its formation. Tourism Management, 29 (2): 263-277.

81. Šegota, T. (2015). Bosnia and the destruction of cultural heritage. Journal of Heritage Tourism, 11 (2): 199-200. 
82. Šegota, T., and Jančič, Z. (2013). Are You Feeling Nostalgic, Neighbour? Academica Turistica, Tourism E Innovation Journal, 6 (2): 3-16.

83. Šegota, T.; Mihalič, T. and Kuščer, K. (2016). The impact of residents' informedness and involvement on their perceptions of tourism impacts: The case of Bled. Journal of Destination Marketing and Management, 1-11. (http://doi. org/10.1016/i.jdmm.2016.03.007).

84. Syssner, J. (2010). Place branding from a multi-level perspective. Place Branding and Public Diplomacy, 6: 36-48.

85. Szondi, G. (2007). The role and challenges of country branding in transition countries: The Central and Eastern European experience. Place Branding and Public Diplomacy, 3: 8-20.

86. Szondi, G. (2008). Public diplomacy and nation branding: Conceptual similarities and differences. International Relations, 1-52.

87. Tasci, A. D. A.; Gartner, W. C. and Cavusgil, T. S. (2007). Conceptualization and Operationalization of Destination Image. Journal of Hospitality $\&$ Tourism Research, 31(2): 194-223.

88. The Economist. (2006). Happy days in Novi Sad. Retrieved February 21, 2007. (http://www.economist.com/node/7155250).

89. UNWTO. (2002). Destination Management \& Quality Programme: Conceptual Framework. Retrieved June 29, 2016. (http://destination.unwto.org/content/).

90. UNWTO. (2015). Tourism Highlights 2015 Edition. Madrid, Spain: United Nations World Tourism Organization. Retrieved March 25, 2016. (www.unwto. com/tourismhighlights).

91. Urde, M. (1999). Brand Orientation: A Mindset for Building Brands into Strategic Resources. Journal of Marketing Management, 15(1-3): 117-133.

92. Urry, J. and Larsen, J. (2011). The Tourist Gaze 3.O. London: Sage.

93. Urry, J. (2002). The Tourist Gaze. London: Thousand Oaks; New Delhi: Sage Publications.

94. Vlada Republike Srbije. (2007). Promovisanje srpskog turizma na CNN-u. Retrieved April 15, 2011. (http://www.srbija.sr.gov.yu/).

95. Volcic, Z. (2009). Neither 'East' nor 'West:' The past and present life of Yugoslav identity (cas Working Paper Series 2/2009). Sofia, Bulgaria: Centre of Advanced Studies Sofia.

96. Yan, J. (2008). Ethical imperatives in nation branding: Smaller nations enter the global dialogue through nation branding, in: Dinnie, K. (Ed.). Nation Branding: Concepts, Issues, Practice (pp. 170-179). Oxford, UK: Butterworth Heinemann Dutton.

97. Zenker, S. and Braun, E. (2010). Branding a city - A conceptual approach for place branding and place brand management, in: Proceedings of the $39^{\text {th }}$ European marketing academy conference, Copenhagen, Denmark. Retrieved April 17. (http://www.placebrand.eu/publications). 
Pregledni rad

Branka Novčić Korać

Sveučilište u Beogradu, Fakultet organizacijskih znanosti, Srbija

e-mail: novcic.branka@fon.bg.ac.rs

Tina Šegota

Sveučilište u Ljubljani, Ekonomski fakultet, Slovenija

e-mail: tina.segota@ef.uni-lj.si

\section{Brendiranje (desti)nacije s narušenim imidžom: slučaj Srbije}

\section{Sažetak}

Članak donosi uvid u to kako je razlikovanje među pojmovima brendiranja nacije i brendiranja turističke destinacije bitno za uspješno rebrendiranje zemlje $s$ negativnim i narušenim imidžom. Na primjeru Srbije autori žele pokazati kako je država razvila konkurentne marketinške strategije s ciljem poboljšanja investicija, izvoza i mogućnosti zapošljavanja, ali nije uspjela razviti koherentnu platformu za upravljanje brendom nacije na najvišoj strateškoj razini. Kroz pregled literature prikazuju se razlike i odnosi između triju pojmova - brendiranja mjesta, brendiranja nacije i brendiranja destinacije. Analizira se sadržaj ključnih inicijativa brendiranja te vizualnih poruka koje su razvile i implementirale Vlada Republike Srbije i Nacionalna turistička organizacija Srbije u periodu od 1996. do 2016. godine. Rezultati analize predstavljeni su kronološki i kroz diskusiju, te su utvrđene poveznice između praksi brendiranja destinacije i brendiranja nacije. Autori su zaključili da se dosad ni jedna od pokrenutih inicijativa nije pokazala uspješnom, većinom zbog slabog ili pogrešnog razumijevanja koncepta brendiranja nacije na najvišem političkom nivou na način da ga se brka s brendiranjem destinacije i turističkom promidžbom. Danas se promocija Srbije ponajviše svodi na predstavljanje države unutarnjim i vanjskim učesnicima kao turističke destinacije.

Ključne riječi: brendiranje nacije, turistička destinacija, imidž brenda, Srbija - postkomunistička zemlja. 